\title{
Sympathetic Symbols, Social Movements, and School Desegregation
}

\author{
MARISELA MARTINEZ-COLA*
}

An important theoretical contribution to the study of social movements involving legal mobilization is framing theory. Framing encourages an analysis of the parties involved and the tools used to make meaning of their cause. A scholarly gap emerges, however, when considering the race, gender, and class of the litigants and the social challenges they face. In this article, the author blends framing theory with controlling images theory to provide a conceptual tool of "the sympathetic symbol" to analyze the effects of race, gender, and class. Next, the author introduces the legal and social histories of two school desegregation cases involving Chinese American and Mexican American plaintiffs, identifying the relevant controlling images germane to each case. Finally, the author questions whether a sympathetic symbol is necessary to counter the raced, gendered, and classed stereotypes that threaten the struggle for equality and suggests future directions for research.

\section{INTRODUCTION}

Scholars who study social movements as well as race have recently suggested that a theoretical and empirical gap exists within the literature and research on social movements. Joyce Bell, for example, suggests that, “...a lack of attention to research on black movements [inhibits] the development of the methodological and theoretical tools available to students of social movements on the whole." ${ }^{11}$ She argues that much of the literature on social movements is privileged by whiteness and fails to take into account the complexities of race even though its theoretical frameworks were rooted in the Civil Rights Movement (CRM). Glenn E. Bracey further observes that when it comes to the study of social movements, "Blackness shape[s] the character and substance of Black antiracist mobilization, but whiteness shapes most analysis of their efforts."

\footnotetext{
*Marisela Martinez-Cola, Emory University Department of Sociology, 1555 Dickey Dr., Atlanta, GA 30322 memart6@emory.edu

The author thanks Dr. Irene Browne, Dr. Timothy Dowd, Dr. Rick Rubinson for their support and Dr. Melissa Weiner for her assistance with this paper. She also thanks the reviewers for their insightful comments and feedback. ${ }^{1}$ J. Bell, 'Introduction to the Special Issue on Black Movements' (2016) 49 Sociological Focus 1.

${ }^{2}$ G. E. Bracey II, 'Black Movements Need Black Theorizing: Exposing Implicit Whiteness in Political Process Theory,’ (2016) 49 Sociological Focus, 11.
} 
While Bell and Bracey refer specifically to Black movements, I argue that these studies also leave out the social movements and experiences of other historically oppressed groups such as Latinos, Asian Americans, and Indigenous peoples. Furthermore, in addition to race, much of the literature does not consider the intersecting effects of class and gender on the development, growth, and trajectory of social movements. In an effort to connect these two goals, I introduce the concept of a sympathetic symbol by blending two critical theories that have yet to be connected in a meaningful manner: framing processes and controlling images. The blending of these two theories invites social movement, race, and legal scholars to question the selection, development, and role of a movement's representative. Therefore, the theoretical question for this article becomes: Is the strategic use of a sympathetic symbol necessary for a social movement to overcome the racialized, gendered, and classed imagery surrounding a movement?

Answering these questions exposes a challenge that many attorneys who represent social movement actors and activists need to consider as they select their plaintiffs. In one of his most controversial writings, legal scholar Derrick Bell, Jr. uses school desegregation case law to demonstrate the conflict attorneys face when they are inherently "serving two masters." 33 On the one hand, an attorney has a responsibility to represent her client's needs to the best of her ability, regardless of the evidence or merits of the case, and obtain the best possible result. On the other hand, an attorney who is committed to social justice is also keenly aware of an organization's message and the overall goal of their movement. What happens then, when the client is not necessarily good for the movement? What happens when the representative of a social movement is not sympathetic? One of the most famous examples is the Montgomery Bus

\footnotetext{
${ }^{3}$ D. Bell, Jr., 'Serving Two Masters: Integration Ideals and Client Interests in School Desegregation Litigation' in Critical Race Theory: The Cutting Edge, eds. R. Delgado and J. Stefancic (2013).
} 
Boycotts when the NAACP opted to select Rosa Parks as their representative rather than the extraordinarily intelligent, yet visibly pregnant, Claudette Colvin. ${ }^{4}$

As Derrick Bell suggests, school desegregation cases offer tremendous guidance when considering these theoretical questions. This article offers, as empirical evidence, two relatively unknown school desegregation cases that occur long before the historic Brown v. Board. The first, Tape v. Hurley $(1885)^{5}$, is a Chinese American school desegregation case that possesses a sympathetic symbol but fails to overcome the culturally embedded conceptions of Chinese. The second, Mendez v. Westminster $(1947)^{6}$, is a Mexican American school desegregation case that effectively utilizes their sympathetic symbol to combat stereotypes and generate substantive change.

For the remainder of this article, I define the concept of a sympathetic symbol by defining and merging theories related to framing processes and controlling images. Doing so provides the theoretical and analytical tools necessary to question the role that race, gender, and class play when studying an ideal plaintiff or representative of legal mobilization. Second, I outline the legal and social history of the Tape and Mendez cases to introduce the plaintiffs, their families, their legal representatives, and the officials representing the school systems. Third, utilizing secondary sources, newspaper articles, court transcripts, and interviews, I identify and name the prevailing controlling images surrounding each case. Fourth, I interrogate how each case deployed their sympathetic symbols. Finally, I explain how the lessons from these cases may be of use to social movement organizers and activists. The overall goal of this paper is to provide a conceptual tool for which to analyze the representatives of social movements.

FRAMES, IMAGES, AND SYMPATHETIC SYMBOLS

\footnotetext{
${ }^{4}$ D. L. McGuire, At the Dark End of the Street: Black Women, Rape, and Resistance (2010).

${ }^{5}$ Tape v. Hurley [1885] 66 Cal. 473 (Supreme Court in California, 1885).

${ }^{6}$ Westminster School Dist. of Orange County v. Mendez [1947] 161 F.2d. 781 ( $9^{\text {th }}$ Cir.).
} 
Defining the concept of a sympathetic symbol requires a blending of social movement theory, specifically framing theory, and Patricia Hill Collins' theory on controlling. Beginning with the influential work of Charles Tilly in the 1970s, the study of social movements has spawned an impressive collection of the research on collective action, protest, and social change ${ }^{7}$ From examining broad, global political crisis to critically analyzing specific, national, social protests of the 1960s, there is no shortage of subjects available for research ${ }^{8}$. The strategies activist, protestors, organizers, and participants use are given various names, including, but not limited to, cultural repertoires ${ }^{9}$ claim making ${ }^{10}$, and dramaturgy ${ }^{11}$. While there may be scholarly discord regarding critical theoretical differences between these strategies, there is one central theme that underlies them all: performance. Protest, in large part, requires performance. ${ }^{12}$ Across all social movement scholarship there is an unacknowledged agreement with the famous Shakespearean line, "All the world's a stage. And all the men and women merely players."

Nowhere is this aspect of performance more apparent than in the legal struggle for equality. There is an implicit understanding within law that social movements, legal mobilization, and litigation are ultimately performances that its participants play out on a local, national, and/or international stage. Litigants are often the stars of a public play for pity, understanding, outrage and, ultimately, change. From the Scottsboro Boys to the Little Rock Nine, individuals embroiled in very public, legal battles possess a name and a narrative to help the awaiting public digest complex legal issues. Thurgood Marshall also understood that a

\footnotetext{
${ }^{7}$ For excellent reviews see D. McAdam, J.D. McCarthy and M.N. Zald, Comparative Perspectives on Social Movements: Political Opportunities, Mobilizing Structures, and Cultural Framings (1996); R. D. Benford and D.A. Snow, 'Framing Processes and Social Movements: An Overview and Assessment' (2000) 26 Annual Rev. of Sociology 611; C. Tilly and L.J. Wood, Social Movements, 1768-2008 (2009).

${ }^{8}$ C. Tilly and S. Tarrow, Contentious Politics (2007).

${ }^{9}$ C. Tilly, Regimes and Repertoires (2010).

${ }^{10}$ D. McAdam, S. Tarrow, and C. Tilly, Dynamics of Contention (2001).

${ }^{11}$ R. D. Benford and S.A. Hunt, 'Dramaturgy and Social Movements: The Social Construction and Communication of Power' (1992) 62 Sociological Inquiry 36.

${ }^{12}$ E. Goffman, The Presentation of Everyday Self (1959).
} 
courtroom battle is only the beginning. "We knew then," he explains, "the court was not the final solution. Many of us knew the final solution would have to be politics."13

Sociologists who have increasingly focused their research on the law also recognize the aspect of performance inherent in the struggle for equality. Using Snow et al.'s frame theory, sociologists have examined the Civil Rights Movement, ${ }^{14}$ Equal Employment Opportunity laws, ${ }^{15}$ the Women's Movements, ${ }^{16}$ and Marriage Equality ${ }^{17}$ to identify and analyze the various tools activists, attorneys, and organizations use to direct collective action, generate messages, make social claims, clarify legal claims, or inspire legal action. Activists, these studies explain, develop strategies that define a cast of characters, create a collective identity, and guide action within and around a particular social movement. ${ }^{18}$ While Benford and Snow identify various forms of "framing" such as motivational framing, collective action framing, and prognostic framing, this paper focuses exclusively on master frames and injustice frames. ${ }^{19}$

A master frame describes a social movement's efforts by multiple social movements players who engage in meaning making activities and messaging across time. This allows researchers to expand the analysis of specific groups and political efforts without limiting a study to a particular time or historical event. Benford and Snow explain that master frames can act as a "master algorithm that colors and constrains the orientations and activities of other movements"

\footnotetext{
${ }^{13}$ T. Marshall, 'The Equality Speech' (November 18, 1978) cited in The Barrister $<$ http://thurgoodmarshall.com/theequality-speech/

${ }^{14}$ D. McAdam, Political Process and the Development of Black Insurgency, 1930-1970 (1982).

${ }^{15}$ P. Burstein, 'Legal Mobilization as the Social Movement Tactic: The Struggle for Equal Employment Opportunity' (1991) 96 American J. of Sociology 1201.

${ }^{16}$ N. Pedriana, 'From Protective to Equal Treatment: Legal Framing Processes and Transformation of the Women's Movement in the 1960s' (2006) 111 American J. of Sociology 1718.

${ }^{17}$ V. Taylor, K. Kimport, N. Van Dyke and E.A. Andersen, 'Culture and Mobilization: Tactical Repertoires, SameSex Weddings, and the Impact on Gay Activism' (2009) 74 American Sociological Rev. 865.

${ }^{18}$ Benford and Hunt, op. cit., n. 11; R.D. Benford and D.A. Snow, 'Framing Processes and Social Movements: An Overview and Assessment' (2000) 26 Annual Rev. of Sociology 611.

${ }^{19}$ There are many other theorists who offer similarly compelling, theoretically grounded models and terminology such as tactical repertoires, fields and cultural "toolkits" (see Isaac 2008 for an excellent summary). My use of frame theory is not an indictment of said terminology. My use of frame theory is designed to be inclusive, not restrictive, of those studies.
} 
to create more collective action frames that are "sufficiently broad in interpretive scope, inclusivity, flexibility, and cultural resonance"20. They also explain that even though research is sparse on the subject master frames can span historical periods as well. ${ }^{21}$ Master framing, then, makes the Tape and Mendez cases, which are separated by 60 years, empirically relevant and theoretically connected to the study of social movements. These school desegregation cases, I argue, are part of what historians call "the long civil rights movement."22

An injustice frame, as theorized by Gamson et al., identifies the violation of a shared moral principle by some external, overbearing authority. ${ }^{23}$ One of the salient markers of injustice frames is the manner "in which movements identify the 'victims' of a given injustice and amplify their victimization" against an unjust authority. ${ }^{24}$ Researchers use this frame to study of campaigns for missing children, ${ }^{25}$ environmental justice, ${ }^{26}$ LGBT rights, ${ }^{27}$ and the rights of crime victims. ${ }^{28}$ In each of these studies, identifying with and developing sympathy for the victims of injustice are paramount to their success. Missing children need protection. The Earth needs preservation. Loved ones need safety. Victims of crime need a voice. In the case of school desegregation...children deserve access to a quality education. For the purposes of this paper, I propose a combined master injustice frame to identify and compare the cast of characters, victims, and cultural and political messaging across the Tape and Mendez cases.

20 id., at 618-619

$21 \mathrm{id}$.

22 J.D. Hall, 'The Long Civil Rights Movement and the Political Uses of the Past' (2005) 91 The J. of American History 1233; J. Stein, "Why American Historians the "Long Civil Rights Movement"' (2012) 11 American Communist History 55; G. Minrose, Remembering Medgar Evers: Writing the Long Civil Rights Movement (2013)

${ }^{23}$ W. A. Gamson, B. Fireman, and S. Rytina, Encounters with Unjust Authority (1982)

${ }^{24}$ Benford and Snow, op. cit., n. 18, at 615.

25 J. Best, 'Rhetoric in Claims-Making: Constructing the Missing Children Problem,' (1987) 34 Social Problems 101.

${ }^{26}$ S. Capek, 'The "Environmental Justice” Frame: A Conceptual Discussion and an Application' (1993) 40 Social Problems 40

${ }^{27}$ V. Jenness, 'Social Movement Growth, Domain Expansion, and Framing Processes: The Gay/Lesbian Movement and Violence against Gays and Lesbians as a Social Problem' (1995) 42 Social Problems 145.

${ }^{28}$ F. J. Weed, 'The MADD Queen: Charisma and the Founder of Mothers Against Drunk Driving' (1993) 4 The Leadership Quarterly 329. 
The next theoretical step is to consider the types of images that lie within a master injustice frame. Lawyers and social movement scholars understand that trials and social movements are ultimately performances played out by its participants on a local, national, and/or international stage. A movement's representative is the star of a public play for pity, understanding or outrage. For example, Taylor et al. show how the American Civil Liberties Union (ACLU) very strategically chose couples in deeply committed, loving relationships to represent the fight for marriage equality. ${ }^{29}$ In one case, the ACLU selects Phyllis Lyon and Del Martin, two white women partnered for 51 years to be the first couple married once marriage licenses were validated. No doubt their status as "historic figures in the gay and lesbian movement" was also critical to their selection. ${ }^{30}$ In another case, US v. Windsor, the attorneys effectively use Edith Windsor's tragic love story to challenge the United States to recognize her thirty-year legal, Canadian marriage. ${ }^{31}$ When Windsor's wife, Thea Spyder, died in 2009, she had to pay estate taxes because the Defense of Marriage Act (DOMA) did not afford them federal protection of the estate-tax exemption for surviving spouses. Time Magazine described Windsor as child of Russian immigrant parents, who lived a secret life, while earning her masters degree, and beginning a successful career working for IBM. Her partner, Spyder, was "a striking beauty with a sharp, analytical mind...who came from a wealth family in Holland, spoke Dutch, played the violin beautifully and had been thrown out of Sarah Lawrence for kissing a woman."32 This invites the question: would both cases have been successful if the plaintiffs were young, gay, male, interracial couples?

\footnotetext{
${ }^{29}$ Taylor, op. cit., n.17.

30 id.

${ }^{31}$ United States v. Windsor, 570 U.S. 12 (2013)

32 E. Gray, 'Edith Windsor: The Unlikely Activist' Time Magazine 11 December 2013, 2 <http://poy.time.com/2013/12/11/runner-up-edith-windsor-the-unlikely-activist/2/>
} 
Another example is the AIDS awareness campaigns and movements of the early 1990s. For several years, the public narrative characterized AIDS as the "gay cancer" and received little to no federal funding. ${ }^{33}$ However, once Ryan White and Arthur Ashe became the "the innocent victims" of the AIDS crisis, public outcry, donations and federal funding skyrocketed. This sympathy culminated with the passage of the 1990 Ryan White Act. ${ }^{34}$ In Ryan White and Arthur Ashe the AIDS movement finally (and tragically) had someone the public could relate to in a deeply personal way. AIDS was no longer a disease affecting sinners, druggies or the sexually promiscuous. It affected "real people" whose young and talented lives were tragically cut short through no fault of their own. Each of these social movements was able to construct what many successful social movements throughout history have possessed, a victim of injustice with whom to identify.

While social movement scholars articulate how to identify and promote victims of injustice, one area where they fall short is examining the role of race, class, and gender in the selection and construction of the victim or victims. The work of Patricia Hill Collins makes clear that such a symbol is not only raced, but also classed and gendered. ${ }^{35}$ "Within U.S. culture," she explains, "racist and sexist ideologies permeate the social structure to such a degree that they become hegemonic, namely, seen as natural, normal and inevitable." 36 The strongest way these ideologies disseminate in society is through popular culture by inundating the American imagination with such images. As bell hooks argues popular culture is the "primary pedagogical

\footnotetext{
33 T. R. Oliver, 'The Politics of Public Health Polity' (2006) 27 Annual Rev. Public Health 195.

${ }^{34}$ D. Whitman, 'To a poster child, dying young' U.S. News and World Report, 16 April 1990, 8; Oliver, id.

${ }^{35}$ P.H. Collins, Black Feminist Thought 2009.

${ }^{36}$ Collins, id.
} 
medium for masses of people globally who want to, in some way, understand the politics of difference." 37

Focusing specifically on Black women, Collins identifies and explains how the controlling images of mammies, matriarchs, jezebels, and welfare queens are used in popular culture to disempower, sexualize, criminalize, and disenfranchise Black women. "Controlling images," Collins argues, "are designed to make racism, sexism, poverty and other forms of social injustice appear to be natural, normal and inevitable parts of every day life." ${ }^{\natural 3}$ Feminist and race scholars have identified other gendered controlling images across all forms of media including, but not limited to, advertising, ${ }^{39}$ film, ${ }^{40}$ comic strips, ${ }^{41}$ and other forms of television and media but they use the phrases myths or stereotypes to describe them. ${ }^{42}$

Despite Collins invitation to find points of connection between historically oppressed group, much of the scholarship on controlling images focuses on the challenges specific to Black women. ${ }^{43}$ While Golash-Boza is an example of more inclusive scholarship, her focus is on television and media. ${ }^{44}$ By examining of the historical and social context of the Tape and Mendez cases, I identify controlling images related to Mexican American and Chinese American women and girls. In the meantime, what we learn by blending the scholarship on master injustice framing and controlling images is that activists, organizers, and lawyers for social movements can exercise what little agency they possess to offer an alternative to the images "controlling" the American, hegemonic, and racist imagination. This alternative is a concept called the

\footnotetext{
${ }^{37}$ b. hooks (writer) and S. Jhally (director), 'Cultural Criticism and Transformation' (1997) [Video Recording transcript], at 2

${ }^{38}$ Collins, op. cit., n. 35 , at 77

${ }^{39}$ J. Kilbourne, 'Deadly Persuasion: Why Women and Girls Must Fight the Addictive Power of Advertising' (1999).

${ }^{40}$ M. Haskell, 'Holding My Own In No Man's Land' (1997).

${ }^{41}$ M. Crawford and R. Unger 'Women and Gender: A Feminist Psychology' (2004)

${ }^{42}$ T. M. Golash-Boza, 'Race and Racisms: A Critical Approach' (2015).

${ }^{43}$ Collins, op. cit., n. 35.

${ }^{44}$ Golash-Boza, op. cit., n. 42.
} 
sympathetic symbol of a social movement. An examination of the Tape and Mendez cases allows us to question how plaintiffs can mediate the popular misconceptions of their movement if their representative is a sympathetic symbol.

\section{A TALE OF TWO PLAINTIFFS}

While the legal records list Joseph Tape and Gonzalo Mendez as the lead plaintiffs, their daughters, Mamie and Sylvia, represent the real lead plaintiffs. Very little scholarship addresses the significant role these young girls play in becoming objects of disdain and subjects of public sympathy. As the classic cast of characters within this master injustice frame, Mamie and Sylvia represent the victims who struggle against the injustice of racist school boards, superintendents, and state legislatures determined to keep California schools White. They represent two similar casts of characters performing similar plays with similar plot lines who obtain disparate results because Tape was defined by controlling images while Mendez made the critical leap of "controlling the image." The Mendez family and their attorney, David Marcus, successfully transform their plaintiff into a sympathetic symbol for their cause.

The Tape family represents the classic immigrant "success story" (see Figure 1). The mother, Mary Tape, is born in 1857 in Northern China, near Shanghai, and immigrates to the United States in 1868 when she is 11 years old. ${ }^{45}$ While the specific circumstances of her immigration are unknown, the fate of many Chinese girls her age is domestic service, slavery or prostitution. ${ }^{46}$

\footnotetext{
${ }^{45}$ L. Gamble, 'What a Chinese Girl Did: An Expert Photographer and Telegrapher' The Morning Call, 19 November 1892, 12.

${ }^{46}$ P. Pascoe, 'Relations of Rescue: The Search for Female Moral Authority in the American West' (1990); J. Yung, 'Unbound Feet: A Social History of Chinese Women in San Francisco' (1995); R. Takaki, 'Strangers from a Different Shore: A History of Asian Americans' (1998); W. R. Jorae 'The Children of Chinatown: Growing Up Chinese American in San Francisco, 1850-1920' (2009); M. Ngai, 'The Lucky Ones: One Family and the Extraordinary Invention of Chinese America' (2010).
} 
She lives alone for five months in San Francisco's Chinatown before being "rescued" by the San Francisco Ladies Protection and Relief Society ("The Society"), a middle-class women's service organization that build an orphanage in Chinatown. ${ }^{47}$ While it is not clear what her life is like during those first five months in the U.S., the Society's mission is to "render protection and relief to strangers, to sick, and dependent women and children," suggesting that she needs protection. ${ }^{48}$ In 1871, she comes under the guardianship of the Society and takes on the Irish name of the assistant matron, Mary McGladery. ${ }^{49}$ She lives with the Society for five years, learns English, acquires "American manners," assists the Society in recruiting orphaned Chinese girls, and ultimately meets and marries a fellow Chinese immigrant named Chew Diep (aka Joseph Tape). ${ }^{50}$ By 1884 , they have three children: Mamie, age 8, Frank, age 6, and Emily, age 4.

According to historian Mai Ngai, the Tapes are one of the few "Americanized Chinese" who manage to assemble an impressive upper-class life complete with "touring cars, hunting dogs, a family compound in Berkeley, California and society weddings." ${ }^{51}$ From poor immigrants to model citizens, the Tapes represent the kind of family that bootstrap polemics use as an example that the American Dream is achievable except for one significant detail. They are Chinese at a time when anti-Chinese sentiment is at its highest.

\section{[Figure 1 approximately here]}

In 1884, Joseph attempts to enroll his daughter a school closest to their home but the school administrator, Jennie Hurley, refuses her admission. With the support of the Chinese Consulate, he sues the San Francisco Public School system for refusing to admit their American-

\footnotetext{
${ }^{47}$ Gamble, op. cit., n. 45.

${ }^{48}$ D. Krah, 'Finding Aid to the San Francisco Ladies' Protection and Relief Society,' [Background information]. San Francisco Ladies' Protection and Relief (MS 3576), (2007).

${ }^{49}$ Ngai op. cit., n. 46. The California Historical Society (CHS) houses the papers of the Society including detailed minutes and diaries of its members. Archival research provides more detailed information about Mary's time in the orphanage.

${ }^{50}$ Gamble, op. cit., n. 45, at 12.

${ }^{51}$ Ngai op. cit., n. 46, at ix.
} 
born daughter. According to state law, the California school system requires the admission of all students regardless of race. ${ }^{52}$ Bound by law, the judge rules in favor of the Tapes and orders the school to admit Mamie Tape immediately. In his ruling, however, the judge advises the school board to appeal to the legislature if they desire a change in law. ${ }^{53}$ Following his advice, the school board appeals the case and lobbies the state legislature.

The Tapes win again on appeal. Nevertheless, the superintendent, Richard Moulder, stalls Mamie's admission until the California legislature passes a law giving local school boards the authority to create a separate Chinese school. ${ }^{54}$ The school board calls a special meeting and votes to create a separate Chinese school. ${ }^{55}$ Once opened, the school has only six pupils, two of which are the Tape children. ${ }^{56}$

Chinese schools continue to exist until 1947 when Mexican-American families challenge the "separate but equal" policies in California schools. Similar to the Tapes, the Mendez story is also a classic immigrant success story. In 1926, Felícitas Gomez, as a young child, moves with her family from Puerto Rico to Arizona to work in the cotton fields. ${ }^{57}$ Because of deplorable working conditions and unjust wages, her family quit and moves to California where Felícitas meets and marries Gonzalo Mendez. They work together on a farm for three years, open a café, and eventually purchase three homes within Orange County. ${ }^{58}$ The Mendez family dream, however, is to own their own farm.

They fulfill their dream by using a tragic, yet inspiring, method. In 1943, their banker introduces them to the Munemitsus, a Japanese American family who are subject to Executive

${ }^{52}$ Ward v. Flood, 48 Cal. 36 (1874)

${ }^{53}$ Tape v. Hurley, op. cit., n. 5.

${ }^{54}$ Author Unknown, 'Mamie Tape Outwitted,' Daily Alta California, 8 April 1885, 1.

55 id.

${ }^{56}$ Author Unknown, 'Chinese School Opened Yesterday,' Daily Alta California, 14 April 1885, 1.

${ }^{57}$ J. McCormick and C. Ayala, 'Felícita "La Prieta" Mendez (1916-1998) and the End of Latino School Segregation in California' (2007) 19 CENTRO Journal 13. 2007.

${ }^{58}$ P. Strum, 'Mendez v. Westminster: School Desegregation and Mexican-American Rights,' (2010). 
Order 9066 requiring Japanese Americans families to relocate to various internment camps across the West. ${ }^{59}$ In order to avoid having their land repossessed by the government, the Munemitsus and Mendez family cleverly enter into an agreement where Gonzalo Mendez leases and maintains their 40 -acre asparagus farm, keeping all profits, until the Munemitsus return. ${ }^{60}$ The Mendez family moves into the neighborhood near the farm and send their children, Sylvia, age 9, Gonzalo, Jr., age 8, and Gerónimo ("Jerome"), age 7, to enroll in Westminster Elementary (see Figure 2).

\section{[Figure 2 approximately here]}

Accompanied by their Aunt Soledad Vidaurri and her two daughters, the Mendez children attempt to enroll in the local school but are denied. The admissions teacher explains, "We will take those," pointing to the Vidaurri children "but we won't take those three," pointing to the Mendez children. ${ }^{61}$ The school officials classify the Vidaurri daughters as either Belgian or French Americans because of their light skin complexion and last names. ${ }^{62}$ The Mendez children, however, are according to Felícitas Mendez, "igual de prietos que yo" ("black/dark like me"). ${ }^{63}$ Consequently, the school official informs them that they must attend the Mexican school further from their home. Vidaurri returns home with all the children and reports the incident to Gonzalo Mendez.

Outraged by the slight, Mr. Mendez, in vain, appeals to various school officials. He argues that, as a tax-paying citizen, his children should be allowed to attend Westminster. The school board stands firm explaining that a perfectly "equal" Mexican school is available for his

\footnotetext{
${ }^{59}$ Strum, id.

${ }^{60}$ Strum, id.

${ }^{61}$ M. Nance, 'The Landmark Decision That Faded Into Historical Obscurity,' (2007) 24 Diverse Issues in Education at 29.

${ }^{62}$ McCormick \& Ayala, op. cit., n. 57; Nance, id.; Strum, op. cit., n. 58.

${ }^{63}$ McCormick \& Ayala, op. cit., n. 57, at 26.
} 
children. According to Sylvia Mendez, however, the school is significantly below subpar. It is situated near a cow pasture, the books are clearly second hand editions, and the children eat their lunch on the ground ${ }^{64}$ With no other alternative available, Mr. Mendez considers legal recourse.

One of the farm's truck drivers informs him about David Marcus, an attorney who successfully sued the city of San Bernardino for refusing to allow Mexicans and Mexican Americans to use of the public pool ${ }^{65}$ In various parts of Orange County, public pools designate Mondays as "Mexican Days," similar to the Jim Crow South. Public officials order the pool drained every Monday evening in order to clean and prepare it for whites to use for the remainder of the week. ${ }^{66}$ San Bernardino, however, refuses to have "Mexican Days" and bars all Mexicans from its public pool. David Marcus sues on behalf Ignacio Lopez, an American citizen, University of California graduate, World War II veteran, and translator for the California's Division of War Information, as well as 8,000 other residents of "Mexican and Latin descent and extraction" and wins.

Gonzalo Mendez reaches out to David Marcus and hires him to sue the school district. Together, they rally the community and begin a four-year legal journey for public school integration. ${ }^{67}$ Representing 5,000 Mexican-American children from four school districts, Gonzalo Mendez and four other families file suit in federal district court, challenging the constitutionality of segregated Mexican schools under the Fourteenth Amendment. The lower court rules in favor of the family and the school districts appeals. On appeal, the Ninth Circuit rules in a unanimous decision that,

\footnotetext{
${ }^{64}$ C. Yoshiko Kandil, 'Mendez v. Segregation: 70 Years Later, Famed Case 'Isn't Just about Mexicans. It's About Everybody Coming Together' Los Angeles Times, 17 April $2016<\mathrm{http}: / /$ www.latimes.com/socal/weekend/news/tnwknd-et-0417-sylvia-mendez-70-anniversary-20160417-story.html>

${ }^{65}$ Lopez v. Seccombe, 71 F. Supp. 769 (1944).

${ }^{66}$ Strum, op. cit., n. 58.

${ }^{67}$ Strum, id.
} 
By enforcing the segregation of school children of Mexican descent against their will and contrary to the laws of California, the respondents have violated federal law... by denying them the equal protection of the laws. ${ }^{68}$

The school district votes not to appeal the case to the Supreme Court and the Governor of California successfully lobbies the state legislature to integrate all California public schools declaring Chinese, Mexican, and Indian schools unconstitutional. The Mendez case never makes it into the classic civil rights narrative because it is not appealed to the Supreme Court and its legal relevance ultimately subsides. ${ }^{69}$ Nonetheless, Tape and Mendez represent the beginning and end of segregated schools in California.

\section{THE HISTORICAL CONTEXT OF CONTROLLING IMAGES}

To understand how Mamie and Sylvia emerge as sympathetic symbols in this battle for equality, I situate the cases in their historical and cultural context and identify the salient controlling images surrounding their respective communities. An examination of newspapers, films, and secondary research show that Asian women and girls are characterized as pagans, prostitutes or poor creatures and Mexican women and girls are mamacitas, malinches or mentally inferior. After introducing these controlling images, I use newspaper articles, court transcripts, and interviews to demonstrate how Tape ineffectively and Mendez effectively used their status as sympathetic symbols to their advantage.

The relevant time frame for Tape case is the mid to late 1800s as the United States experiences its first group of Chinese immigrants. The presence of women is small and limited as

\footnotetext{
${ }^{68}$ Westminster v. Mendez, 161 F. 2d. 781 (9 ${ }^{\text {th }}$ Cir. 1947) p. 781.

${ }^{69}$ For other Brown/Mendez connections see R. R. Valencia (2005) 'The Mexican American Struggle for Equal Educational Opportunity in Mendez v. Westminster: Helping to Pave a Way for Brown v. Board of Education' 107 Teachers College Record 389; L. Y. Ramos (2004) 'Dismantling Segregation Together: Interconnections between Mendez v. Westminster (1946) and Brown v. Board of Education (1954) School Segregation Cases' 37 Equity and Excellence in Education 247; F. P. Aguirre (2005) 'Mendez v. Westminster School District: How it Affected Brown v. Board of Education,' 4 Journal of Hispanic Higher Education 321; V.L. Ruiz (2003) "“We Always Tell Our Children They Are Americans": Mendez v. Westminster and the California Road to Brown v. Board of Education' 2000 College Board Review 20; T.A. Saenz (2004) 'Mendez and the legacy of Brown: A Latino Civil Rights Lawyer’s Assessment’ 15 Berkeley La Raza Law Journal 67.
} 
there are only seven women for every 4,018 men in San Francisco. ${ }^{70}$ As more and more Chinese immigrate, their labor goes from a necessity to a threat. As a result, by 1870, an array of laws limiting Chinese rights to immigrate, give testimony, intermarry with Whites, and own land soon follows. ${ }^{71}$ Efforts to exclude the Chinese begin with the imposition of numerous taxes thereby limiting their value and pay and eventually culminate in the Chinese Exclusion Act of 1882. This time frame provides the historical backdrop to the harsh Anti-Chinese immigration policies that precede the 1885 Tape case.

The relevant time frame for Mendez case is from the late 1920s to 1950. This time period is also characterized by massive immigration from Mexico and major changes in U.S. Mexico relations involving the Mexican repatriation efforts of 1929-1939, the Bracero Program of 1942 and The Good Neighbor Policy. High levels of participation by Mexican Americans in WWII also marked this era. Furthermore, two significant events dominate Los Angeles newspapers just before the Mendez trial: the 1942 criminal trial of People v. Zamora also known as the "Sleepy Lagoon murder case" and the 1943 Zoot Suit riots.

These time frames capture the cultural milieu of each case allowing me to identify the following salient controlling images:

\begin{tabular}{|l|c|c|}
\hline Racial Group & Controlling Images & Time Period \\
\hline Chinese Women and Girls & Pagans, Prostitutes and Poor Creatures & $1850-1900$ \\
\hline Mexican Women and Girls & Mamacita, Malinche and Mentally Inferior & $1920-1950$ \\
\hline
\end{tabular}

\section{Pagans, prostitutes and poor creatures}

Historians, Judy Yung, ${ }^{72}$ Ronald Takaki, ${ }^{73}$ and Wendy Rouse Jorae ${ }^{74}$ provide some of the richest descriptions of the lives of Chinese women and children in the late 1800s in San Francisco.

\footnotetext{
${ }^{70}$ Yung, op. cit., n. 46.

71 Yung, op. cit., n. 46; Takaki, op. cit., n. 46.

72 Yung, id.
} 
Specifically, they shed light on the three prevailing images I identify as pagans, prostitutes and poor creatures.

Probably one of the most powerful images of the Chinese, in general, is that of the heathen. Decades of anti-Chinese sentiment identify the Chinese as "...immoral and diseased heathen, and unassimilable aliens. ${ }^{" 75}$ In 1870, for example, Bret Harte, a noted American author and poet, publishes a poem in the Overland Monthly called "The Heathen Chinee." The poem and the phrase become so popular that the New York Globe publishes it twice. ${ }^{76}$ As the image below demonstrates, the Chinese of California are characterized as lazy, drunk, violent, and completely hedonistic (see Figure 3).

[Figure 3 approximately here]

It is at this intersection of time and space that missionaries express their deep commitment to enlightening "heathen" Chinese women. Quoting an 1881 annual report Jorae demonstrates how missionaries frequently "contrast between light and dark, cleanliness and filth, or heathenism and Christianity" in their work. ${ }^{77}$ Visiting a Chinese home, Ms. Cable, a reformer, writes

Setting aside all feelings of loathsomeness born of the repulsive act of this filth and darkness, I entered upon the task of illuminating a soul of corresponding degradation, speaking to her of God's love, pure air and sunshine, contrasting these with her present surroundings. Each succeeding visit found a growing appreciation of my words, 'till finally she became as thoroughly nauseated with her surroundings as myself. Today we find her in a cheerful room at 822 DuPont Street, which she has thoroughly cleaned, whitewashed and papered. ${ }^{78}$

\footnotetext{
${ }^{73}$ Takaki, op. cit., n. 46.

${ }^{74}$ Jorae, op. cit., n. 46.

${ }^{75}$ Yung, op. cit., n. 46, at 22.

${ }^{76}$ Takaki, op. cit., n. 46, at 104.

${ }^{77}$ Jorae, op. cit., n. 46, at 72 .

${ }^{78}$ Jorae, id.
} 
Such diary entries reveal that heathen Chinese women, while filthy, savage and diseased, are nonetheless salvageable and, if trained properly, are also fully capable of becoming part of a "civilized" American society. For the purposes of this paper, instead of using the phrase heathen, I will use the more popular synonym pagan to describe this controlling image.

The next most pervasive controlling image is that of the Chinese prostitute. According to Takaki, locals call prostitutes “lougeui ('always hold her legs up') and baak haak chai ('hundred men's wife')." ${ }^{.79}$ In the 1870s, most of the prostitutes are either stolen by a brothel owner or sold by their parents "for as little as $\$ 50$ and then resold in America for as much as $\$ 1,000 . " 80$ Without legal or diplomatic representation, they enter into service contracts with clauses like, "If Ah Ho shall be sick for any time for more than ten days, she shall make up by an extra month of service for every ten days' sickness." ${ }^{" 81}$ Due to menstrual cycles, illnesses, or even unwanted pregnancies, such clauses extend contracts indefinitely. ${ }^{82}$ According to Yung, Chinese prostitutes are characterized, “...in books, magazines and newspapers as.... 'reared to a life of shame from infancy'...[and] are also guilty of 'disseminating vile diseases capable of destroying 'the very morals, the manhood and health of our [read white] people. ${ }^{\prime \prime 3}$

The final controlling image most prevalent in the narrative about Chinese women and girls is that of the pathetically poor creature. They are called mui tsai, which, in Cantonese, means "little sister." ${ }^{44}$ The mui tsai are largely responsible for serving the home in any capacity an owner sees fit, including taking care of children, cleaning the home and being "on call" at any time of the day or night. ${ }^{85}$ Under a Confucian ideology, these young girls are to be submissive

\footnotetext{
${ }^{79}$ Takaki, op. cit., n. 46, at 122.

${ }^{80}$ Yung, op. cit., n. 46, at 27.

${ }^{81}$ Yung, id., at 17.

${ }^{82}$ Takaki, Yung, Jorae, Pascoe, op. cit., n. 46.

${ }^{83}$ Yung, op. cit., n. 46, at 32.

${ }^{84}$ Yung, id., at 37.

${ }^{85}$ Yung, Jorae, op. cit. n. 46.
} 
and obedient to their, "father at home...husband in marriage... and eldest son when widowed." 86 Furthermore, because these girls could not carry on the family lineage, they are at risk for being "sold, abandoned, or drowned during desperate times." ${ }^{87}$ This largely explains why mui tsai are mostly little girls. Census data confirms that in 1880 , the time closest to the trial, many Chinese children in San Francisco are either at home or work as servants, cooks, or gardeners (see Table 1).

\section{[Table 1 approximately here]}

In these times, the benevolent actions of maternal missionaries rally to "rescue" these poor creatures. According to historian Peggy Pascoe, the most powerful image in missionary's writings, literature and reports is that of the "Chinese slave girl." 88 Missionary women, answering the call to rescue young girls sold into domestic service, capitalize on this image. Determined to interrupt the "... hateful practice of buying and selling their women like so much merchandise," missionaries often make these girls the target of their rescue operations. ${ }^{89}$ As outlined above, Mary Tape, herself, was a beneficiary of these types of organizations.

The controlling images of the pagan, prostitute, and poor creature represent two distinct and extreme representations of Chinese women and girls. Chinese women are sexualized and criminalized while Chinese girls are infantilized. Mamie Tape, as the lead plaintiff of the case, was neither. Instead she occupies a middling position where she is too young to be a sexual object or a hardened criminal and too wealthy to be a poor creature.

2. Mamie Tape: "The same as other Caucasians..."

\footnotetext{
86 Yung, op. cit., n. 46, at 18-19.

${ }^{87}$ Yung, op. cit., n. 46, at 18.

${ }^{88}$ Pascoe, op. cit., n. 46, at 53

${ }^{89}$ Pascoe, id., at 121
} 
As previously described, the Tapes are a thoroughly Americanized Chinese family. They possess American names, live outside of Chinatown, and only speak English. Nonetheless, a review of twelve newspaper articles from the Daily Alta California regarding the Tape case make it is clear that even the Americanized Tapes did not escape the pagan controlling image. A reporter describes Mamie and her brother Frank as "a pair of little heathens." Superintendent of Public Instruction accuses the Tapes of pretending to be "converted to Christianity in order to learn English." ${ }^{91}$ At a meeting of the Board of Education, James H. Culver declares that:

...those brave men who signed that immortal declaration.... Never thought their descendants would permit heathen temples with idolatrous worship to be reared beside our churches dedicated to the living God, or that the barbarous dim of gongs or invocation of gods of wood should rise and mingle with the sweet church bell., ${ }^{92}$

Such pagan imagery paints the Tapes as non-Christian, non-English speaking, and ultimately unworthy.

Having their Christianity questioned publicly, Mary Tape retaliates by publicly challenging the school board's Christianity. In a letter to the Board of Education she writes:

Dear sirs...Didn't God make us all!!!...I suppose you all goes to churches on Sunday! Do you call that a Christian act to compell my little children to go so far to a school that is made in purpose for them $[\mathrm{sic}] .^{93}$

The issue, however, is that she questions their Christianity but does not confirm her own. Instead, her letter could be publicly perceived as the ranting of an angry, uneducated mother. Furthermore, the letter comes too late. She writes and mails it after the school board decides to create a separate Chinese school. Throughout the ordeal, reporters obsessively follow and

\footnotetext{
${ }^{90}$ Author Unknown, 'The Chinese School' Daily Alta California, 10 April 1885, 8.

${ }^{91}$ Author Unknown, ‘The Chinese Question' Daily Alta California 15 January 1885, 8.

${ }^{92}$ Author Unknown, 'Director Culver's Speech' Daily Alta California 2 April 1885, 1.

93 Tape, Mary, 'A Letter from Mrs. Tape’ Daily Alta California 16 April 1885, 1.
} 
describe the family in detail without mention of their strong ties to their local Presbyterian Church or connection to the Society. ${ }^{94}$ Consequently, this aspect of the Tape family's life is never captured or reported in the local newspaper.

The Tape family also did not escape the vitriol normally reserved for the criminal elements like prostitutes or poor creatures. According to Director Culver, Mamie Tape is part of a "long, sinuous, blue-bloused, wooden-shod, stealthy-treading Mongolian monster." 95 The school board argues for separate schools by claiming that, “...the mingling of Mongolian and Caucasian races in the public schools will be fraught with disastrous consequences to our civilization and to our institutions." ${ }^{96}$ The State Superintendent explains that the admission of Chinese children would "drive many of the Caucasian children out of the schools." ${ }^{.97}$ In a speech to the school board, he asks, "Shall we neglect our own children for the Chinese who are thrusting themselves on us?"98 Finally, School Superintendent Moulder proclaims that, "He was not ashamed to avow his belief in the existence of a natural feeling of dislike to the people of the Chinese race." ${ }^{\prime 99}$ The school officials make it clear that Mamie Tape is not one of their own children. Instead, she is a "monster" and a disastrous threat to their civilization and institutions that will always be subject to a natural feeling of dislike.

The Tape family could not be further from this characterization. In fact, on Mamie's first day in the new Chinese school, a reporter observes that she is, “...gorgeously attired in American clothes, including pink stockings and a light-colored leghorn hat, provided with an ostrich plume of immense proportions." 100 Their status and "difference" may have been useful to the case if

\footnotetext{
${ }^{94}$ Ngai, op. cit., n. 46.

${ }^{95}$ Author Unknown, 'Director Culver's Speech' Daily Alta California 2 April 1885, 1.

${ }^{96}$ Author Unknown, 'Chinese in Our Schools' Daily Alta California 10 January 1885, 1.

${ }^{97}$ Author Unknown, op. cit., n. 91, at 8.

${ }^{98}$ Author Unknown, id.

${ }^{99}$ Author Unknown, op. cit., n. 54, "Mamie Tape Outwitted," 1885, 1.

100 Author Unknown, 'Chinese School' Daily Alta California 14 April 1885, at 1.
} 
this description had been reported before the school board's decision or when the school first refused Mamie admission. A fascinating family, the Tapes were definitely worthy of reporting. Unfortunately, an article that could have helped them came seven years too late.

In 1892, Leland Gamble, a reporter for the San Francisco Morning Call visits the Tape family home. What prompts the visit is a rumor that there is a "Chinese girl" who is a photographer in her spare time. In the late 1800s it was unheard of for women to be in photography much less a Chinese woman. ${ }^{101}$ Upon meeting Joseph Tape, Gamble writes, "On being asked if the story was true that his wife understood photography, he answered with a laugh and said in as good English as I ever heard in my life: 'Yes, sir, and a good many other things too'." ${ }^{\prime 02}$ Joseph Tape invites him into the home, which, the reporter describes as:

.... a cozy little parlor furnished with the best of taste...an upright piano, on the top of which rested a French horn and a zither...a combination library and specimen case [with] a goodly array of books... [and] some beautiful specimens of California birds [which] had all been shot by the master of the house." 103

He describes Mrs. Tape in the following manner:

Mrs. Tape...is dressed in a gown of soft clinging silk or some Indian stuff which set off her figure to good effect. Her hair was arranged in the latest American fashion and was as black and glossy as ever graced the head of Andalusian beauty. Her face was comely, one might even say pretty, because it had so much intelligence and was set off by a fine mouth behind which were a set of pearly teeth. ${ }^{104}$

The accolades do not stop there. Upon learning that, "Mamie is quite proficient in piano," he writes:

I expressed a desire to hear the young lady play and imagine my surprise when without any of the backwardness and diffidence of American girls of the same age she took her seat at the piano and began to finger the keys... to play the "Mocking-bird" and brought

\footnotetext{
${ }^{101}$ Wexler, Tender Violence: Domestic Visions in the Age of U.S. Imperialism, 2000.

${ }^{102}$ Gamble, op. cit., n. 45, at 12.

${ }^{103}$ Gamble, op. cit., n. 45 , at 18 .

${ }^{104}$ Gamble, op. cit., n. 45, at 12.
} 
out its notes as well as I have ever heard them brought out by an American girl. ${ }^{105}$

In this article, Mary Tape stands in stark contrast to the earlier descriptions of Chinese prostitutes. She is regal compared to them. Mamie, because she dresses like an American girl and plays piano better than an American girl, is far from a poor creature. The article is almost a tribute to the Tape family complete with illustrations of Mary Tapes professional photographs. The reporter makes it clear to his San Francisco readers that this Chinese family is different. He writes:

"I had always been accustomed to view the Chinese in an entirely different light; but when I saw around me the father, the mother and their accomplished children I changed my opinion in regard to the race in general." 106

What if this article had appeared at the same time the Tape family filed suit? How many other minds would have been changed? Would the public have been outraged at how the school board treated this assimilated family? Would Mamie have been worthy of American education? Their faith, Mamie's impressive piano skills, and the Tapes Americanized identity did not reach the public until it was too late. She lost the legal battle and was forced to attend the Chinese school furthest from her home. The Tape family, their attorney, and the Chinese Consulate could not to capture the American imagination and position themselves as sympathetic symbols in the pursuit of the American Dream.

\section{The mamacita, malinche and mentally inferior}

As for Mexican American women and girls in the 1920s-40s, I rely on the scholarship of Women Studies, American Studies, and Chicano Studies scholars and historians to identify and describe the mamacita, malinche and mentally inferior controlling images. Similar to Chinese women

\footnotetext{
105 Gamble, id.

${ }^{106}$ Gamble, op. cit., n. 45, at 18.
} 
and girls, the scholarship shows how, Mexican women and girls were also racially othered with sexualized, criminalized, and infantilized controlling images.

The first and probably most well known controlling image is that of the "spicy senorita" or the mamacita. Clara Rodriguez explains Hollywood's hunger for the spicy senorita in her review of Latinos in film. ${ }^{107}$ According to Rodriguez, with the advent of sound in films, one particular Mexican actress, Lupe Vélez, dominates the spotlight.

Because she is bilingual, she is one of the few Mexican actresses able to crossover into American films in the 1940 s as the industry moves from silent films to "talkies." A comedic actress, she plays a character that speaks in highly exaggerated, broken English and is prone to fits, temper tantrums, and frequent outbursts in Spanish. According to Rodriguez, the press describes her as, "Just a Mexican wild kitten."108 A simple review of the titles of her films demonstrates the popularity of her mamacita persona. Her films are The Girl From Mexico (1939), Mexican Spitfire (1940), Mexican Spitfire Out West (1940), Mexican Spitfire’s Baby (1941), Playmates (1941), Mexican Spitfire at Sea (1942), Mexican Spitfire Sees a Ghost (1942), Mexican Spitfire's Elephant (1942) and Mexican Spitfire's Blessed Event (1943). Her character, Carmelita, is a "hot-blooded, south-of-the-border Latina" and a "feisty, in-your-face- hot tamale, defiant of traditional conventions and seemingly independent of male and industry controls." 109

The next controlling image is that of the pachuca or the malinche. In Mexican folklore, La Malinche is an indigenous woman who helps the Spanish conquer Mexico by serving as translator to Spanish conquistador Hernán Cortés and offers her body as the vessel for creating a new mestizo (mixed) race. The term malinche refers to troublemakers, race traitors, and

\footnotetext{
${ }^{107}$ C. E. Rodriguez (2011) 'Delores del Rio and Lupe Velez: Working in Hollywood, 1924-1944' 6 NorteAmerica 69.

${ }^{108}$ Rodriguez, op. cit., n. 107, at 73.

${ }^{109}$ Rodriguez, id., at 80.
} 
temptresses. Catherine Ramirez identifies the 1940s zoot suit wearing pachuca of Los Angeles as the modern day malinches. ${ }^{110}$

In 1940s Los Angeles, the public is very familiar with the zoot suit because of the 1942 Sleepy Lagoon murder case and the 1943 Zoot Suit riots. The local media describes the Sleepy Lagoon case as a gang fight between two groups of pachucos that results in the death of one man, the arrests of 600 Mexican American men and women, and the conviction of 17 young men. ${ }^{111}$ Shortly after their convictions, 200 white servicemen raid East Los Angeles for ten days, attacking any zoot suiter they find by stripping him of his clothing, cutting his hair, and viciously beating him. ${ }^{112}$ What soon follows is a Los Angeles City Council resolution banning zoot suits making it clear that the zoot suit is indicative of criminality. In a time when the country is rationing heavily for the war, the zoot suit is excessive, indulgent and unpatriotic.

Pachucas, female zoot suiters, are also subject to public scrutiny. They are not only criminalized but also highly sexualized by the White and Mexican press. The general look of the pachuca involves tight-fitted clothing, ratted, bouffant hair, and heavy makeup with dark lipstick. Ramirez (2009) explains, “...they appeared to betray middle-class definitions of feminine beauty and decorum." $" 113$ They are also undesirable with the Mexican community. In an article from the local Spanish-language newspaper, La Opinión, a writer reports that,

Las malinches wore 'falda negra y muy corta' (very short black skirts), that they painted their faces-in particular their lips and eyes- 'en una manera escandalosa' (in a scandalous manner) and that they punctuated their racy ensembles with a bushy head of matted hair soaked in grease. ${ }^{114}$

\footnotetext{
${ }^{110}$ C.S. Ramirez, 'The Woman in the Zoot Suit: Gender, Nationalism and the Cultural Politics of Memory' (2009).

${ }^{111}$ Ramirez, id.; Strum, op. cit., n. 58.

112 G. Sanchez, 'Becoming Mexican American: Ethnicity, Culture and Identity in Chicano Los Angeles, 1900-1945' (1993); Ramirez, op. cit., n. 110.

${ }^{113}$ Ramirez, id., at 38.

${ }^{114}$ Ramirez, id., at 70-71.
} 
What Ramirez describes is that the controlling image of the malinche violates the politics of respectability among Whites and Mexicans.

The final and most damaging controlling image is that of the mentally inferior Mexican child. This image dominates the discourse on education in the 1940s. For example, Juan Perea, a critical race theorist and legal scholar, explains how teachers use genetic determinism to conclude that Mexican American children are less intelligent than White children. He writes that, "Mexican American students are considered to have low intelligence and inferior academic potential, as measured by "intelligence tests" of questionable validity." 115 Using the phrase, "the pobrecito [poor thing] syndrome," Perea goes on to explain how the mentally inferior stereotype still continues to manifest even today. "Current research demonstrates that Latino students continue to be tracked toward vocational and technical courses...[and] are systematically overrepresented in classes for the educable mentally retarded."116

The mental inferiority of Mexican children also comes from a perceived lack of cleanliness (that is the dirty Mexican stereotype). Historian George Sanchez (1993), describes the reasoning behind the dirty Mexican stereotype as written in a 1929 manual called Americanization through Homemaking:

Sanitary, hygienic, and dietetic measures are not easily learned by the Mexican. His [sic] philosophy of life flows along the lines of least resistance and it requires far less exertion to remain dirty than to clean up. ${ }^{117}$

Perea also describes how, even years after Mendez, "Many Anglo teachers and parents advocated for mandatory baths for 'dirty Mexican kids because it will teach them how it feels to be clean.'

115 J. F. Perea (2004) 'Buscando America: Why Integration and Equal Protection Fail to Protect Latinos' 117 Harvard Law Rev. 1420 at 1442.

${ }^{116}$ Perea, id, p. 1443 citing A. Carrasquillo, 'Profile of Hispanic Students in United States Public Schools' W. Laija and S. H. Ochoa, 'Historical Roots of Politics and Policies Regarding the Education of Hispanics: The Mexican American Experience' in C. Teddlie, A. Tashakkori, H. Ochoa, and E. Kemper (Eds.) 'Education of Hispanics in the United States: Politics, Politics, Policies, and Outcomes (Readings on Equal Education)' (1999).

${ }^{117}$ Sanchez, op. cit., n. 112, at 102. 
Another teacher refused to let her Mexican American students hug her without first inspecting their hair for lice."118

Throughout the trial, however, the overriding message from the school district is that Mexican children are mentally inferior and unequal to White students. There is no better evidence of the strength of this controlling image than in the transcripts from the Mendez trial. In response to why the Mexican-American children were separated from White children, Harold Hammerston, a superintendent, says: "We keep them separate and apart because during the first two or three years the teachers that have those children... are better able to get those children to progress more rapidly, when they are with their own group." "19 The judge asks him what would happen if the Mexican children and the White children went to the same school, he replies, "Our tests show that...they are still in lower groups and they are in a lower percentage in grade placement, and mental ability, and everything." 120

Mr. Holden, another superintendent, who admits that 60 per cent of the children in the Mexican school spoke English fluently, is asked why those students are not "afforded the same opportunities or the same privileges" as White students. He replies, "It is the degree of sufficiency... which is still not up to the children of Anglo-Saxon descent."121 In Holden's opinion, children who speak Spanish in the home are forever damaged. "I think this retardation of children...who speak the Spanish language in their homes," Holden testifies, “...well I think that the retardation continues. I would say that there is a degree to which it handicaps the child."122

\footnotetext{
118 Perea, id. n. 115 , at 1442.

${ }^{119}$ Gonzalo Mendez et al. v. Westminster School District of Orange County et al., Trial Transcript no. 62777356277738, Civil Case Files, 1938-2001, U.S. District Court of the United States (California), 1885-2009, Record Group 21, National Archives and Records Administration (Riverside) at 301.

${ }^{120}$ Transcripts, id., at 311.

121 Transcript, id., at 382.

122 Transcript, id., at 384.
} 
Because of their perceived mental inferiority, school administrators also accuse Mexican children of being unfamiliar with cleanliness and hygiene. During the trial, James Kent, another superintendent, testifies, "They must be taught cleanliness and...manners...which ordinarily do not come out of the home." 123 The children's lack of personal hygiene, he testifies, is evident, "In the care of their heads, lice, impetigo, tuberculosis; generally dirty hands, face, neck, ears." ${ }^{124}$ Though he kept no formal records, the Mexican children of his district are considered diseased and dirty health risks. Segregation, in his mind, is the only solution. Mentally inferior Mexican children, according to district officials, are "retarded" in their learning, "handicapped" by their language, and lacked personal hygiene.

4. Sylvia Mendez: "Just as good as he is!"

A review of the court transcripts and interviews make it clear that unlike the Tape family, the Mendez family and David Marcus strategically position their sympathetic symbol before and during the trial. First, Sylvia can never be mistaken for a spicy mamacita or a traitorous, unpatriotic pachuca. As a symbol of angelic purity in her white dress, she does not fit the mamacita or malinche stereotype. Furthermore, her status as a little girl makes her too young to be sexualized in this manner. In her photograph, Sylvia projects an image that is more saint than spitfire.

Their biggest obstacle is to overcome the pervasive image of the mentally inferior Mexican child who is unworthy of and would not benefit from White schools. As a result, the Mendez family and David Marcus make sure that she can never be mistaken for mentally inferior. Similar to the Lopez case, David Marcus utilizes a "we are no different from you" strategy. The strategy is not a proclamation of whiteness, but rather a demand for recognition as

\footnotetext{
123 Transcript, id., at 85.

124 Transcript, id., at 116.
} 
American citizens worthy of the same rights, treatment and opportunities afforded White citizens. In their first letter to the school board dated September 5, 1944, the families write:

It would appear that there is racial discrimination and we do not believe that there is any necessity for it and would respectfully request that you make an investigation into this matter and bring about an adjustment... Some of our children are soldiers in the war, all are American born and it does not appear fair nor just that our children should be segregated as a class. ${ }^{125}$

This was especially important since many Mexican American men are serving valiantly during World War II. Recall that Marcus selects Ignacio Lopez, an American citizen, University of California graduate, World War II veteran, and translator for the California's Division of War Information as the lead plaintiff confirming the importance of military service. Felícitas Mendez, in a 1975 interview, affirms the importance of this strategy when she recalls

...the young boys...when they went and fought [in the war], and they came back with that feeling, that if they were good enough to fight for their country they were good enough to do everything else here. $^{126}$

From the battlefields to the classroom, this message of being "good enough" resonates strongly with Sylvia to this day. In a recording created for StoryCorp, Sylvia recalls how once she began attending the integrated Westminster school, a White boy came up to her and said, "What are you doing here? You don't belong in this school. They shouldn't have Mexicans here." 127 She returns home crying and tells her mother that she no longer wants to attend Westminster. According to Sylvia, her mother replies, "Don't you realize that this is what we fought for? Of course you are going to stay in that school and prove that you are just as good as he is." 128

\footnotetext{
${ }^{125}$ Letter from the parents retrieved http://www.somosprimos.com/sp2012/spfeb12/spfeb12.htm.

${ }^{126}$ McCormick \& Ayala, op. cit., n. 57, at 25-26.

${ }^{127}$ D. Isay, 'Sylvia Mendez and Sandra Mendez Duran' Story Corp, 5 March 2010 [Audio podcast] <www.storycorps.org/listen/stories/>

${ }^{128}$ Isay, id.
} 
In her photograph she is a picture of cleanliness in her white dress and well-groomed hair. In a StoryCorp recording, she recalls, "I remember being in court every day. They [her parents] would dress us up really nice and we'd be there sitting very quietly." 129 During the trial she is dressed nicely and sitting quietly...the exact opposite of a mentally inferior, dirty Mexican. The image of Felícitas Mendez dressing her child for a performance during the trial reminds me how Mary Tape also dressed her child for a performance in front of the reporters but only after losing the case.

In yet another similarity with Mamie Tape, Sylvia Mendez is photographed sitting in front of a piano. This is a signal of her intelligence to master a refined instrument. Sitting there, with her fingers over the keys, in her pressed dressed and pigtails, her little racialized, nine-yearold body is an example that she was anything but mentally inferior. Where and how this photograph is used during the case, however, is unclear. Nonetheless, it is a staged, wellconstructed photograph with a clear message of worthiness.

Sylvia Mendez is not a mamacita, a malinche nor is she mentally inferior. Like Mamie Tape, she is simply the eldest daughter in a middle-class family who are trying to, as Felícitas Mendez testifies, "do the right thing and just asking for the right thing, to put our childrens [sic] together with the rest of the childrens [sic]. ${ }^{130}$ Unlike Mamie Tape, Sylvia Mendez wins her legal battle at both the district court and federal circuit court level. Furthermore, the governor of California successfully lobbies the state legislature to integrate all California public schools. The governor, Earl Warren, goes on to become Chief Justice of the Supreme Court whose first case is Brown v. Board of Education (1954). This suggests that while historically oppressed groups are shut down by systems of inequality that generate oppressive, caricatured controlling images, the

\footnotetext{
${ }^{129}$ Isay, id.

130 Transcript, op. cit., n. 119, at 468-69.
} 
one small area of agency they possess, as demonstrated by Mendez, is the selection and strategic framing of their sympathetic symbol.

\section{CONCLUSION: STRATEGIC USE OF SYMPATHETIC SYMBOLS}

A close, comparative study of the legal and social history of the Tape and Mendez cases offers three potential contributions to social movement literature and its theoretical framework. First, it adds research about the legal mobilization of Latinx and Asian American communities to the framing literature on social movements. Second, it suggests the use of controlling images to examine the role that, in addition to race, gender and class play in the study of social movements. Third, by blending frame and controlling images theory, this article offers a conceptual and analytical tool that explores whether the strategic use of a sympathetic symbol is necessary to offer an alternative to the destructive controlling images set forth in public discourse.

First, both cases offer empirical evidence to analyze through a master injustice frame as theorized by Benford and Snow as well as Gamson. For example, both cases possess an identifiable cast of characters that represent the classic battle of good versus evil. There are the "evil," unjust, and racist school officials who deny "good," little girls the opportunity to attend the school closest to their home. There are parents who will use what resources they have to stand up and fight on behalf of their children. According to the framing literature, the Tape and Mendez families are victims of injustice whose victimhood is captured in newspaper articles, letters, and court testimony. Ultimately, they both represent children who deserve access to a quality education regardless of their race and/or background.

Second, both plaintiffs encountered controlling images that were racialized, sexualized, and criminalized. The "racist and sexist ideologies" of the late 1880s and mid 1940s produced identifiable images such as the pagan, prostitutes, and poor creature as well as the malinche, the 
mamacita, and the mentally inferior. These images, as captured in journals, court testimony, newspapers, and film, were accepted as "natural, normal, and evitable parts of every day life."131 Most importantly, they offered justification to exclude Chinese American and Mexican American children by suggesting they are too criminal, unworthy, or incapable of succeeding in White schools.

Finally, both families and their representatives possessed the opportunity to exercise some level of agency by strategically positioning themselves in the media and in the courtroom as contradictions of controlling images. Mamie and Sylvia's race mark them as poor creatures or mentally inferior, but it is their class and Americanized performance that pushes back against those controlling images. Furthermore their gender and age make them both young enough to be "rescued" from becoming ugly pagans, trouble-making malinches, highly sexual prostitutes or sexually charged mamacitas. Mamie and Sylvia's gender, along with their race, class and youth, frame them both as sympathetic symbols of racial resistance (Figure 4). They occupy a middling position where they are too smart and Americanized to be considered pathetic or dimwitted, and too young to be the criminal, hypersexual stereotypes of their racial groups. The critical difference, however, is that the Mendez family and David Marcus fought to transform their plaintiffs from troublemakers to innocent victims of discrimination from an unjust school system. More importantly, they did so before and during the trial, not after when it is too late.

\section{[Figure 4 approximately here]}

Analyzing the Tape and Mendez cases using framing and controlling images theory results in a conceptual framework that may have application and/or relevance to modern-day struggles for justice. It asks whether or not the representatives of a movement should or need to be cast as sympathetic symbols that challenge the stereotypes generated by a racialized,

\footnotetext{
${ }^{131}$ Collins, opt. cit., n. 35.
} 
gendered, and classed society. There are two potential directions for future research. First, a sample size of two raises a theoretical question but a larger sample size is necessary to test the concept. Future researchers could take a much larger sample size of social movements that are not necessarily limited to school desegregation. Then critically examine the lead representative of the movement to determine if he/she/they are sympathetic symbols that overcome racial, gendered, or classed stereotypes. The representatives of various movements such as Malcolm X, Martin Luther King, Jr., Cesar Chavez, Rodolfo "Corky" Gonzales, Angela Davis, Emmett Till, Vincent Chin, and Ruben Salazar are all interesting subjects to compare to one another and determine if they were sympathetic symbols. A second potential direction is to examine some of the more modern-day movements. For example, are the unarmed victims of police violence represented in the Black Lives Matter (\#BLM) movement sympathetic symbols that contradict the controlling images presented in the media? ${ }^{132}$ Can this concept be applied to the protests against Philippine President Rodrigo Duarte and his "drug war" which has claimed the lives of thousands or the work of Argentinian Mothers of Plaza de Mayo who are still seeking their truth after 40 years? ${ }^{133}$ The plight of these groups is the subject of the ever-growing literature on social movements and law. This article suggests that if social movements, particularly ones involving legal mobilization, are performances as Goffman suggests, then, scholars should not only analyze "the performance" as a whole but also the race, class, and gender of the performers.

\footnotetext{
132 Way, Ray, and Packyetti (2017) Mapping Police Violence, <https://mappingpoliceviolence.org/unarmed/>

${ }^{133}$ France-Presse, A. Public Radio International, 25 February 2017 <https://www.pri.org/stories/2017-02-25/massrallies-and-against-president-philippines-erupt-manila> and Goñi, U., The Guardian, 28 April 2017 <https://www.theguardian.com/world/2017/apr/28/mothers-plaza-de-mayo-argentina-anniversary>
} 
Figure 1

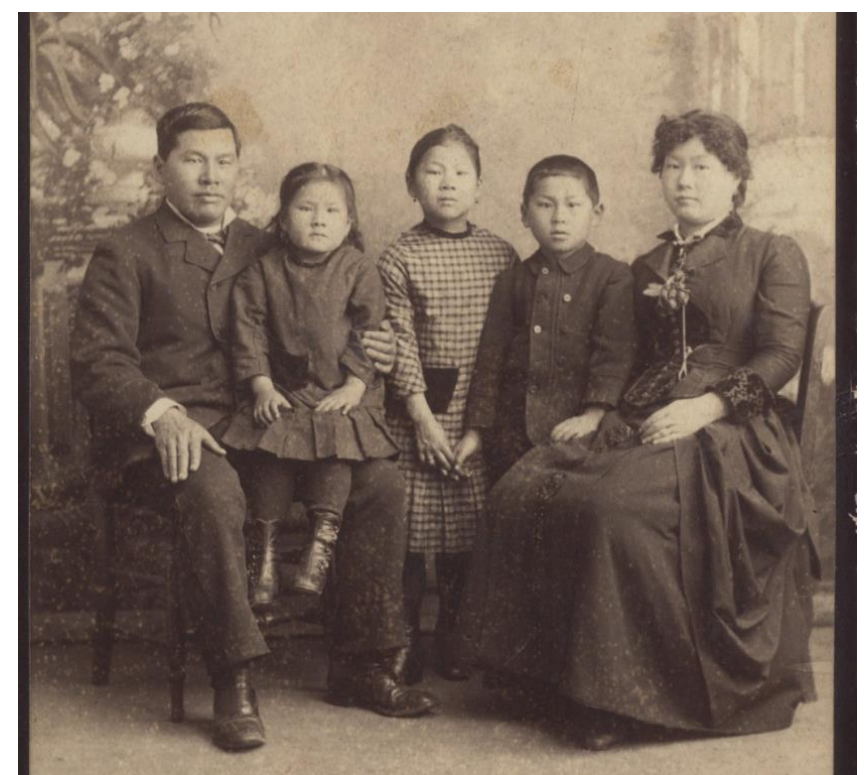

Figure 1: The Tapes (Joseph, Emily, Mamie, Frank and Mary), 1884 
Figure 2

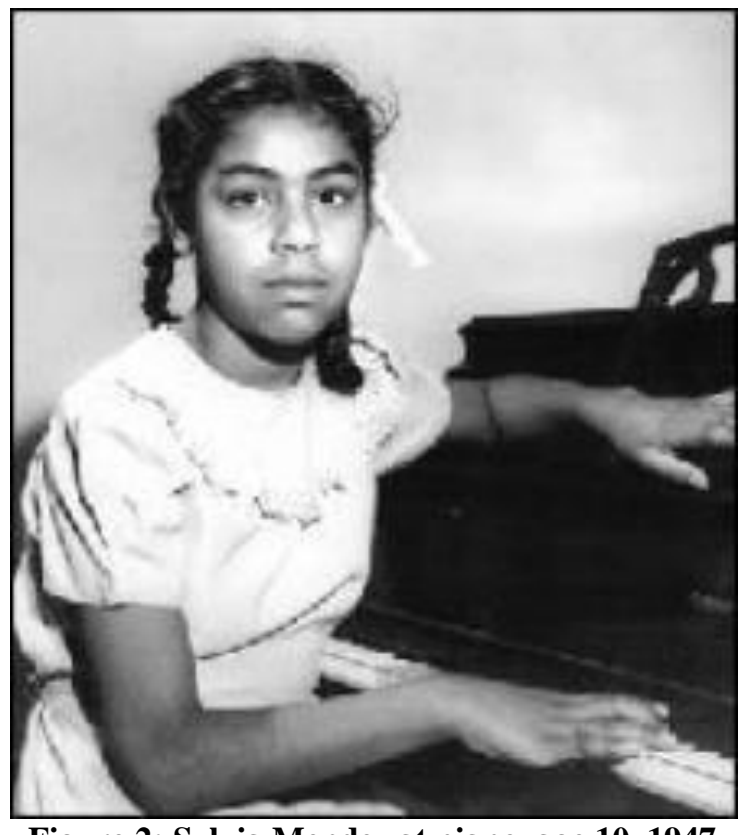

Figure 2: Sylvia Mendez at piano, age 10, 1947 


\section{Figure 3}

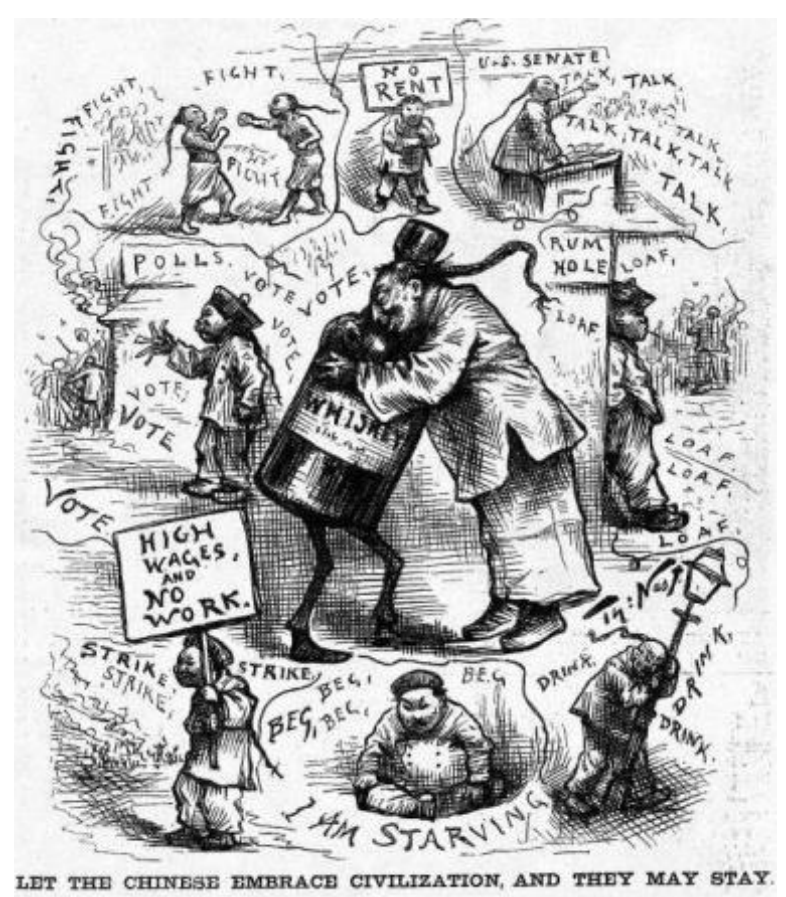

Figure 3: "Let The Chinese Embrace Civilization and They May Stay," Harper's Weekly, March 18, 1882 
Table 1: Occupations of Chinese Children in San Francisco, 1860-1880

\begin{tabular}{|c|c|c|c|}
\hline Occupation & 1860 & 1870 & 1880 \\
\hline $\begin{array}{l}\text { At home/ } \\
\text { none listed }\end{array}$ & $\begin{array}{c}67 \\
(63 \%)\end{array}$ & $\begin{array}{c}444 \\
(29 \%)\end{array}$ & $\begin{array}{c}708 \\
(48 \%)\end{array}$ \\
\hline At school & 0 & $\begin{array}{c}21 \\
(1 \%)\end{array}$ & $\begin{array}{c}82 \\
(6 \%)\end{array}$ \\
\hline $\begin{array}{l}\text { Servant/cook/ } \\
\text { Gardner }\end{array}$ & $\begin{array}{c}4 \\
(4 \%)\end{array}$ & $\begin{array}{c}498 \\
(32 \%)\end{array}$ & $\begin{array}{c}322 \\
(22 \%)\end{array}$ \\
\hline $\begin{array}{l}\text { Laundry/ } \\
\text { washman }\end{array}$ & $\begin{array}{c}1 \\
(1 \%)\end{array}$ & $\begin{array}{c}179 \\
(12 \%)\end{array}$ & $\begin{array}{c}89 \\
(6 \%)\end{array}$ \\
\hline Cigar maker & 0 & $\begin{array}{c}188 \\
(12 \%)\end{array}$ & $\begin{array}{c}60 \\
(4 \%)\end{array}$ \\
\hline $\begin{array}{l}\text { Clothing } \\
\text { manufacturer }\end{array}$ & $\begin{array}{c}1 \\
(1 \%)\end{array}$ & $\begin{array}{c}5 \\
(<1 \%)\end{array}$ & $\begin{array}{c}52 \\
(4 \%)\end{array}$ \\
\hline $\begin{array}{l}\text { Shoe/slipper } \\
\text { Factory }\end{array}$ & 0 & $\begin{array}{c}42 \\
(3 \%)\end{array}$ & $\begin{array}{c}23 \\
(2 \%)\end{array}$ \\
\hline Laborer & $\begin{array}{c}20 \\
(19 \%)\end{array}$ & $\begin{array}{c}49 \\
(3 \%)\end{array}$ & $\begin{array}{c}42 \\
(3 \%)\end{array}$ \\
\hline Prostitute & 0 & $\begin{array}{c}66 \\
(4 \%)\end{array}$ & $\begin{array}{c}33 \\
(2 \%)\end{array}$ \\
\hline Miscellaneous & $\begin{array}{c}13 \\
(12 \%)\end{array}$ & $\begin{array}{c}54 \\
(3 \%)\end{array}$ & $\begin{array}{c}63 \\
(4 \%)\end{array}$ \\
\hline Total & 106 & 1,546 & 1,474 \\
\hline
\end{tabular}

Source: U.S. Census Bureau

Note from Jorae (2009): This data is based on my survey of all Chinese children age sixteen and under in San Francisco. The category of clothing manufacturer in this table includes children whose occupations were listed as seamstress, tailor, embroiderer, sewing machine operator, pant and overall maker, shirt maker, button sewer, or underwear maker. The miscellaneous category included a number of the children employed in the food-service industry (p. 81). 
Figure 4

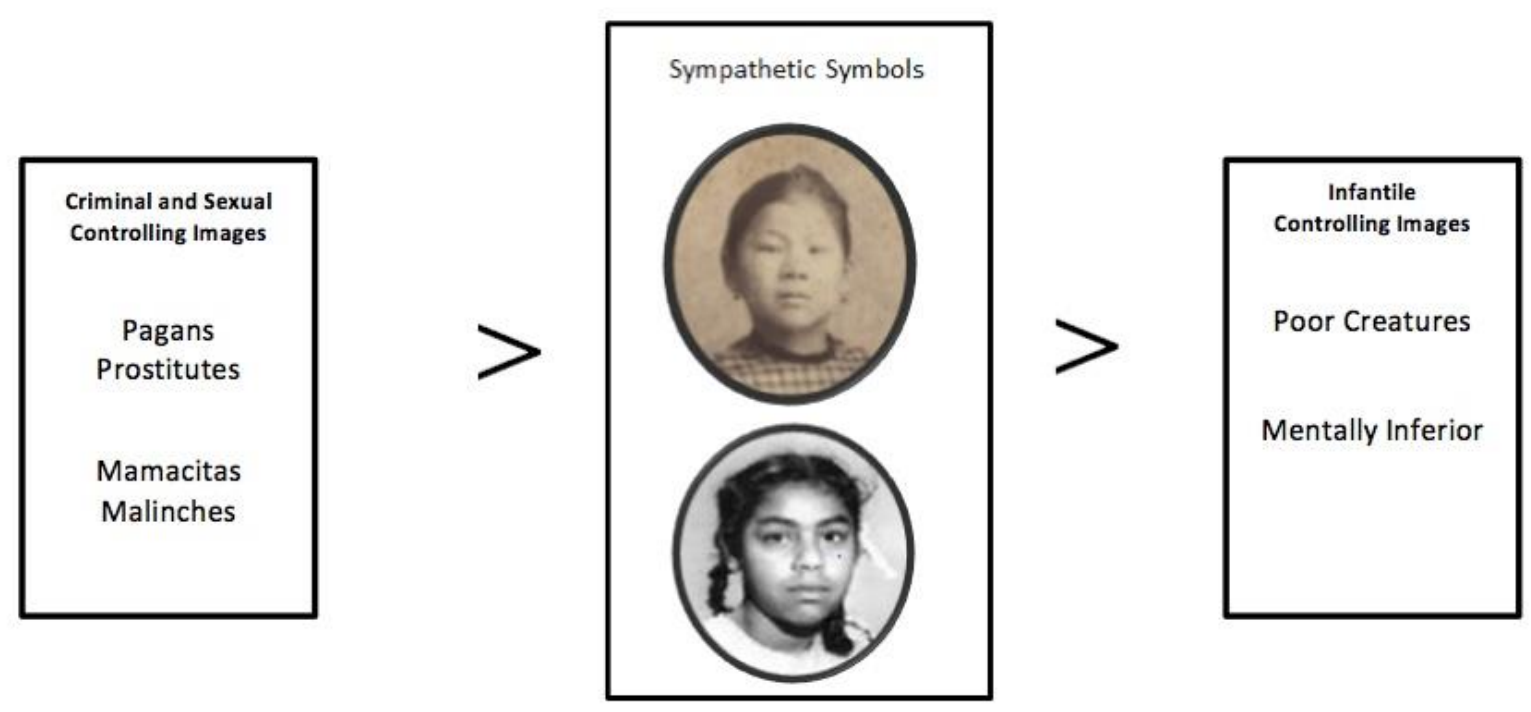

Figure 4: How Sympathetic Symbols of Social Movements Work 